\title{
Research on Collaborative Operation in Xi'an International Land port and Airport
}

\author{
Guoling JIA ${ }^{1,2}$ \\ (1.School of Business, Xi'an International University; Xi'an 710077 \\ 2.School of Highway, Chang'an University, Xi'an 710064)
}

Keywords: Land port; Airport; Logistics function; Collaboration

\begin{abstract}
Xi 'an international land port and airport are the important fulcrums for Shaanxi province to implement the strategy of "One Belt One Road" and to develop its export-oriented economy. Based on the general development situation of $\mathrm{Xi}$ 'an international land port and airport and analyzing their similarities and differences, the external cause and internal cause of synergy are discussed. The contents of synergy from the strategy level, tactics level and business level are explained respectively.
\end{abstract}

\section{Introduction}

$\mathrm{Xi}$ 'an land port and airport are the important nodes in Shaanxi logistics network structure and the key engine to the economic development. At the same time, the location of Samsung project in Xi'an and the national One Belt and One Road Strategy play the certain leading role and influence on the original international logistics pattern. Although the competition between the land port and airport is inevitable, it is more indispensible to conduct collaboration. Fortunately, with the instructions of government, Xi'an International Port Zone has been in an effort to plan and construct "the fast and special freight line", which will help to set up the air-ground three-dimensional network bridge to build a new starting point of the silk road economic belt. To explore the similarities and differences in land port and airport logistics will provide the theoretical basis for both sides to engage in more cooperation and are significant to promote the benign development of the international logistics industry in Shaanxi province.

\section{Logistics Network Layout in Xi'an City}

\subsection{Xi'an International Land port}

Xi' an International land port is founded in 2008, and it is the first inland port approved in China. It is the outcome of outbound economic development policy for inland, and can deal with the bottleneck occurred in the connection between inland area and international trade world. Simultaneously, it contributes to the integration of eastern and western economic and trade operation.

As the inland focus point of sea and land through transport, Xi' an international land port has the advantages of geographical and traffic resources, as well as the various industry base and growing logistics demand market. It has formed the strategic layout with the Type B bonded logistics center as the core, the international logistics zone as the support, the national comprehensive logistics zone and logistics industry concentration area as the wings.

Not only the basic functions of common logistics park can be offered, but also the functions supplied by international port can be provided such as bonded, customs, inspection and quarantine, insurance, settlement of exchange service, etc..

Xi'an international land port can extend the port service function of coastal port to Xi'an, and achieve the integration effect of railway container freight station, comprehensive free trade zone and highway port. As a result, the multimode transport of highway, railway, airway and sea will be achieved, improving the advantage of xi' an transport hub. In turn, the efficiency of logistics will be improved and the logistics cost can be effectively cut down. Furthermore, the development of 
nearby trade industry is boosted to improve the industry aggregation effect. The development orientation of $\mathrm{Xi}^{\prime}$ an international land port is to construct the largest land port and international trade logistics center in the area of upstream and middle stream of Yellow River.

\subsection{Xi'an International Airport}

In July 2013, Shaanxi province put forward to build "air silk road" by relying on airport new town. On May 14, 2014, the national civil aviation administration approved Xi'an Airport New town as the first "national aviation city test area", setting up the gateway and hub for air development in Shaanxi. On October 13, 2014, the general administration of customs, ministry of finance, taxation and foreign exchange administration approved the Xi'an-xianyang airport bonded logistics center. This new airport new town provides the valuable opportunities for Xi'an air transportation to implement the strategy of national airport economic services.

\subsection{Differences and similarities between land port and airport}

Xi'an land port and international airport are the two significant logistics project supported by the government. They have something in common, at the same time; each has its own characteristics. Details are present as table 1:

Table1 Similarities and differences between Xi'an land port and airport

\begin{tabular}{|c|c|c|c|}
\hline & $\begin{array}{c}\text { Comparison } \\
\text { items }\end{array}$ & Land port & Airport \\
\hline \multirow[b]{2}{*}{ Similarities } & Support & Strong support & Strong support \\
\hline & $\begin{array}{l}\text { Logistics } \\
\text { function }\end{array}$ & $\begin{array}{l}\text { Basic logistics function 、 information } \\
\text { processing、 } \\
\text { Through freight、 } \\
\text { Bonded logistics , forwarder、 } \\
\text { Business support service 、 public } \\
\text { administration etc. }\end{array}$ & $\begin{array}{l}\text { Same as the land } \\
\text { port }\end{array}$ \\
\hline \multirow{7}{*}{ Differences } & Foundation time & Founded in 2008 & Founded in 2013 \\
\hline & $\begin{array}{l}\text { International } \\
\text { logistics } \\
\text { dependence } \\
\end{array}$ & Mostly rely on sea port & Conduct it directly \\
\hline & $\begin{array}{l}\text { Multimodal } \\
\text { transport form }\end{array}$ & $\begin{array}{l}\text { Railway and highway; } \\
\text { Railway and sea }\end{array}$ & Highway and air \\
\hline & $\begin{array}{l}\text { International } \\
\text { routes }\end{array}$ & $\begin{array}{c}\text { International freight trains from Xi'an to } \\
\text { Central Asia is normalized, still, the } \\
\text { overall international transport trains is } \\
\text { less }\end{array}$ & $\begin{array}{l}\text { More than } 27 \\
\text { international routes } \\
\text { have been opened }\end{array}$ \\
\hline & Goods source & Wide variety & High value products \\
\hline & $\begin{array}{c}\text { Container } \\
\text { service function }\end{array}$ & Comparatively perfect & imperfect \\
\hline & $\begin{array}{l}\text { Interchange } \\
\text { with highway }\end{array}$ & More & Less \\
\hline
\end{tabular}

\section{Reasons behind the coordinated development of Xi'an international land port and airport[1][2][3][4]}

In the early 1970s, Hermann Haken from the federal Republic of German founded the synergetics, and won the widespread concern in the field of regional cooperation. The purpose is to emphasize on the cooperation between enterprises or industries from the perspective of systems engineering. The " $0-1$ "competition model can be changed into " $1-1$ " competition and cooperation pattern, finally realizes the overall efficiency of " $1+1>2$ " through information and risk sharing, trust 
and win-win relationship.

\subsection{External motivation}

\subsubsection{Policy guidance}

In 2014, the government work report proposed to establish the linkage mechanism between the Xi'an land port and airport; specifically, Xi'an City government work report also demonstrated to actively build comprehensive transportation system and international transshipment hub port. The development of logistics industry and prosperity of the international trade are the first step to create a new starting point of Silk Road economic belt. From the point of macroeconomic policy, the coordinated development of land port and airport is imperative.

\subsubsection{Intense market competition}

Under the background of economic globalization, magnitudes of opportunities both foster the development of logistics industry and bring about the growing competition, mainly in the customer competition, the expansion and optimization of logistics network layout, the reduction of logistics cost and the rising the customer service level, etc.. Land port and airport rely on different transportation mode and are carried out with the aid of highway transportation port connection. It is clear that these two terminals have quite a few competition areas which will get more intense with the time going and increasing of customer requirements. To deal with the new situation, the best way and long-term solution is to transform the vicious completion to orderly cooperation.

\subsection{Internal motive}

\subsubsection{Inherence linkage between logistics nodes}

Despite the logistics functions are professionally divided, still, the value relevance between logistics unit exists. From the perspective of supply chain and value chain, the overall cooperation in sequence and section between logistics unit is the important foundation of value produce and transfer. Both Xi'an land port and airport play a significant part in the layout of Shaanxi logistics network and the conduction of One Belt One Road Strategy. There is business cross and internal close relationship for them, which provide necessary motivation to collaboration.

\subsubsection{Profit drivers}

To pursue the maximum profit is the object of enterprise survival. When measures such as self-structure adjustment and technology innovation have been explored to the greatest extend, it is the time for the enterprise to break the broad to seek new profit source. The logistics resource integration and synergy between land port and airport can further improve customer satisfaction as well as utilization efficiency of logistics resources, which means the reduction of logistics operation cost, and finally help to achieve overall effect of value-added.

\section{Coordination level between land port and airport}

Coordination of Xi'an land port and airport can be divided into strategic synergy, tactical coordination and business synergy.

\subsection{Strategic synergy [5]}

Strategic synergy is based on the collaborative mechanism and cooperative ideas. In this level, the whole logistics network system composed by land port and airport will be conducted qualitative analysis, focusing on key logistics elements, expected income and coordination mechanism. 


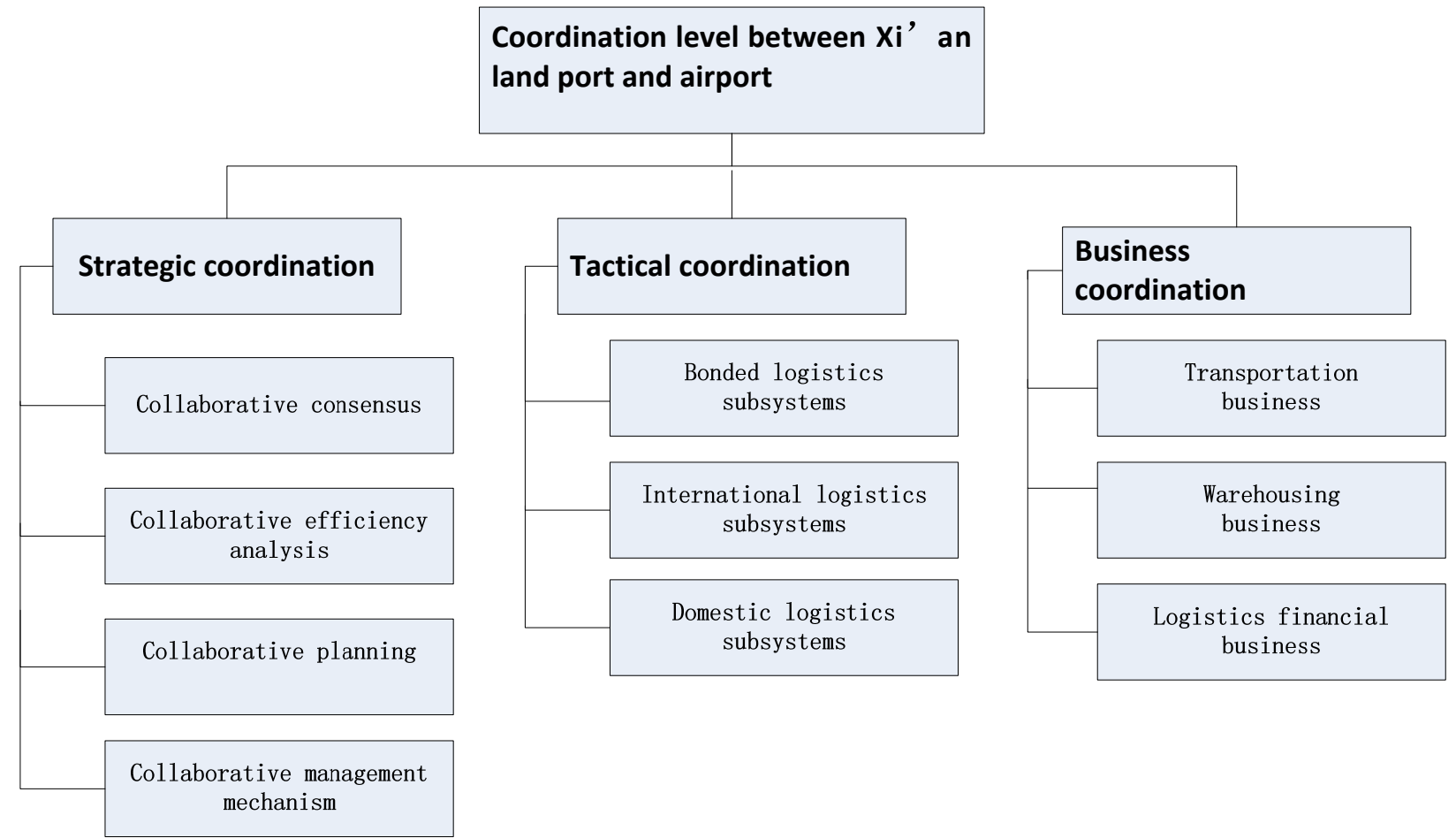

Fig.1 Collaborative levels for Xi'an land port and airport

\subsubsection{Collaborative consensus}

As the main body of collaborative, Xi' an land port and airport need to realize the collaborative effect, then to develop the motivation and effect the action. This is the first step to further deepen the synergy degree and build long-term relations of cooperation.

\subsubsection{Expected synergies analysis}

Based on the expected effect, synergies should meet or exceed forecasts on both sides. On the contrary, if the benefit is not comparable with the effort, it is likely to weaken or undermine motivation. Therefore, it is necessary to establish synergies measure system, mainly including business scale, profits, customer satisfaction and enterprise's development etc..

\subsubsection{Collaborative planning}

The collaborative plan consists of making clear the goals, building synergy management system, positioning the members and acquiring the requirement of the collaborative resources.

\subsubsection{Develop collaborative management mechanism}

First of all, communication technology and management foundation platform for the land port and airport are necessary to be built. Secondly, scientific interests' distribution mechanism is established. Xi'an land port and airport have different interest demands and value orientation. The cooperation relationship will be break either if the benefit distribution is imbalance or if cost for one part is high to achieve the overall benefit. Third, establish an effective risk control mechanism. Benefit and risks coexist. There are such external risks as economic risks, political risks, market risk in addition to internal risk. It is necessary to establish an effective risk prevention and commitment mechanism. Fourth, establish an effective feedback mechanism. Feedback mechanism helps to form dynamic closed-loop optimization system. Experience and the existing problems can be summarized by the system to adjust and guide the future cooperative strategy.

\subsection{Tactical coordination}

Tactical coordination refers to the internal logistics network subsystem collaboration. This paper mainly divided into bonded logistics subsystems, international and domestic logistics subsystems.

\subsubsection{Bonded logistics subsystems coordination}

Xi' an land port comprehensive bonded area is the largest one in Northwest China with the most complete function and the highest opening level. Also, it is linked with highway port and railway container terminal. At the same time, Xi-xian airport bonded area is the special customs surveillance zone aimed to provide service for international air logistics hub. Land port bonded area can undertake airport bonded business, and vice versa. Operation should be conducted in nearer bonded 
area according to the destination and processing requirements. Thus, not only unnecessary turnover is reduced but also traffic congestion can be eased which avoid the resulting time delay and loss.

\subsubsection{International logistics subsystems coordination}

International logistics subsystems coordination mainly refers to customs clearance and multimodal transport development. Based on the city opening-up strategy, cross-sectorial and cross-regional customs clear of land port and airport can be strengthened. Port mechanism is improved to achieve the departments' information exchange, mutual recognition and enforcement of mutual regulation. The integration of customs clearance of land port and airport will create more efficient model of port customs clearance.

\subsubsection{Domestic logistics subsystems coordination}

Domestic logistics subsystems coordination can offer a relatively complete logistics function through effective division. Good business cooperation relationship is established and the domestic logistics operation in integrated. What's more, the structure of logistics industry is optimized and the relevant industries are promoted. As a result, a more powerful logistics network radiation effect is formed.

\subsection{Business coordination}

Xi' an land port and airport business coordination refers to coordination of each logistics business section. This paper mainly discusses the transport, warehousing and financial services business.

\subsubsection{Transport business coordination}

Transport business coordination refers to integrate and optimize the existing land port and airport transportation service resources. The potential of both the infrastructure and each transport mode can be fully developed to form the combined advantage, thus, the rational layout; efficient coordinated transport network is built

\subsubsection{Warehousing business coordination}

Storage business is one of the important functions of land port and international airport logistics network. The dispersed storage silos can be integrated through synergy. Thus, not only redundant construction resources can be avoided, but also the storage facility can be effectively utilized.

\subsubsection{Financial business coordination}

To carry out the financial value-added service based on the logistics platform has become one of the important characters of modern logistics. Companies like the Xi'an Land Bridge International Logistics co.,LTD have been located in land port. Xi-xian airport also lead to the development of trade logistics by its unique air economic advantage. Both land port and airport have the dominant advantage to develop logistics financial business. Green channel built between land port and airport allow the goods mortgage in one place to flow to the other party in advance which saves the circulation time of the goods.

\section{Conclusion}

Land port and airport integration and coordination development will further strengthen the comprehensive transportation function, and improve the competitiveness of the domestic and international logistics in Shaanxi province. Therefore, there is need to set up information platform and physical connection equipment. Also, the mechanism of customs clearance, logistics organization, logistics finance and multimodal transport are supposed to effectively interact to develop a comprehensive, around-clock and three-dimensional transportation hub on the Silk Road economic belt.

\section{Acknowledgement}

This study is sponsored by Shaanxi Social and Science Foundation (13D246) and Shaanxi Science and Technology Department Foundation (2015SF296) 


\section{References}

[1]Fei Yan. Research on Logistics Service Supply Chain Coordination[D]. Chang'an University, 2012:51-56

[2]Li Chen. Research on Multidimensional Organization Coordination Mechanism and Method Based on the common value. Tianjin University,2010:46-47

[3]Chennan Gou. Research on the Linkage Development Between International Land Port and Seaport Based on the Gravity Model. Chang'an University, 201153-54

[4]Changzheng Zhu. Research on International Land Port Mechanism and Layout Planning Theory[D]. Chang'an University, 2010:74

[5]Lei Shi. Research on Integration of Urban and Rural Logistics Network Based on the Theory of Collaboration[D]. Chang'an University, 2011:7-8 